DOI https://doi.org/10.18551/rjoas.2018-04.12

\title{
ACCELERATION OF ECONOMIC POLICY AND IMPLEMENTATION STRATEGY FOR DEVELOPMENT PLANNING IN POOR AREA
}

\author{
Aba Fransiskus X Lara \\ Faculty Economics and Business, Atma Jaya Catholic University of Indonesia \\ ${ }^{*}$ E-mail: fransiskus.lara@atmajaya.ac.id
}

\begin{abstract}
The purpose of this study is to analyze and identify the basic sectors of the economy. The problems that arise are to determine the condition and potential of the economy, how the potential of basic sectors of the economy, economic growth, sectoral contribution, and transformation of economic structure, multiplier effect of the basic sectors to the economy and the prospect of the leading sectors of the economy. Kupang City of East Nusa Tenggara province in Indonesia was chosen as the location of the study to design the development process in this area because the planning process undertaken in this area is a combination of bottom-up and top-down planning approach.
\end{abstract}

\section{KEY WORDS}

Poor areas, economic policy, planning strategy, development structure.

Changes in development strategies can create a strong development and economic structure and be able to address the challenges that will be faced in the future (Alonso. 1968). Besides, with the integration of the world economy, the regional economy must prepare as well as possible in strengthening the foundation of the national economy towards the global economic struggle (Allison, Graham, 1968). The diversity of progress assessed by regions and sectors, partly because of the tendency of investment more oriented to urban areas or regions that have advanced because it has more support facilities and adequate infrastructure (Eichengreen, Donghyung, and Kwanho.; 2012). Thus it is clear that economic development will bring greater inequality and inefficiency if not addressed properly and seriously through a development planning policy (Dolgoff, \& Feldstein, 2009).

Based on the economic conditions occurring in Kupang City, East Nusa Tenggara Province of Indonesia at present and taking into account the economic potential and its role to other regions, it can determine which sector is greater affect the structure of the regional economy in the future. Sectors that are expected to be a priority can be adapted to regional development policies. Therefore, no economic development policy is expected to conflict with the priority sectors in the regional economy. Although it is recognized that every policy is not always in line with the priority of economic forecasts, considering other aspects of the development of a region, but is expected to be considered in development planning (Boschma \& Martin. 2010).

In connection with the description above, for the economy in Kupang City, East Nusa Tenggara Province Indonesia can develop optimally and able to increase income per capita, the policy of economic development planning strategy taken by the government needs to put priority scale on the economic superior sector in the region.

\section{METHODS OF RESEARCH}

The study was conducted using the Spatial Planning in Regions for Growing Economics (SPRING) approach with the result of the discussion to be used for the Framework's work to fit the local situation in the Kupang City the East Nusa Tenggara Province of Indonesia. Field data collection includes primary data as well as secondary data. Secondary data is collected and taken from the State Statistics Office (BPS) and others from relevant technical institutions. When there is a difference between the data from the BPS and the data from the technical institution then the data will be used from the BPS. Secondary 
data is also obtained from the results of research conducted by research institutions that have been doing research in Kupang City of East Nusa Tenggara Province Indonesia.

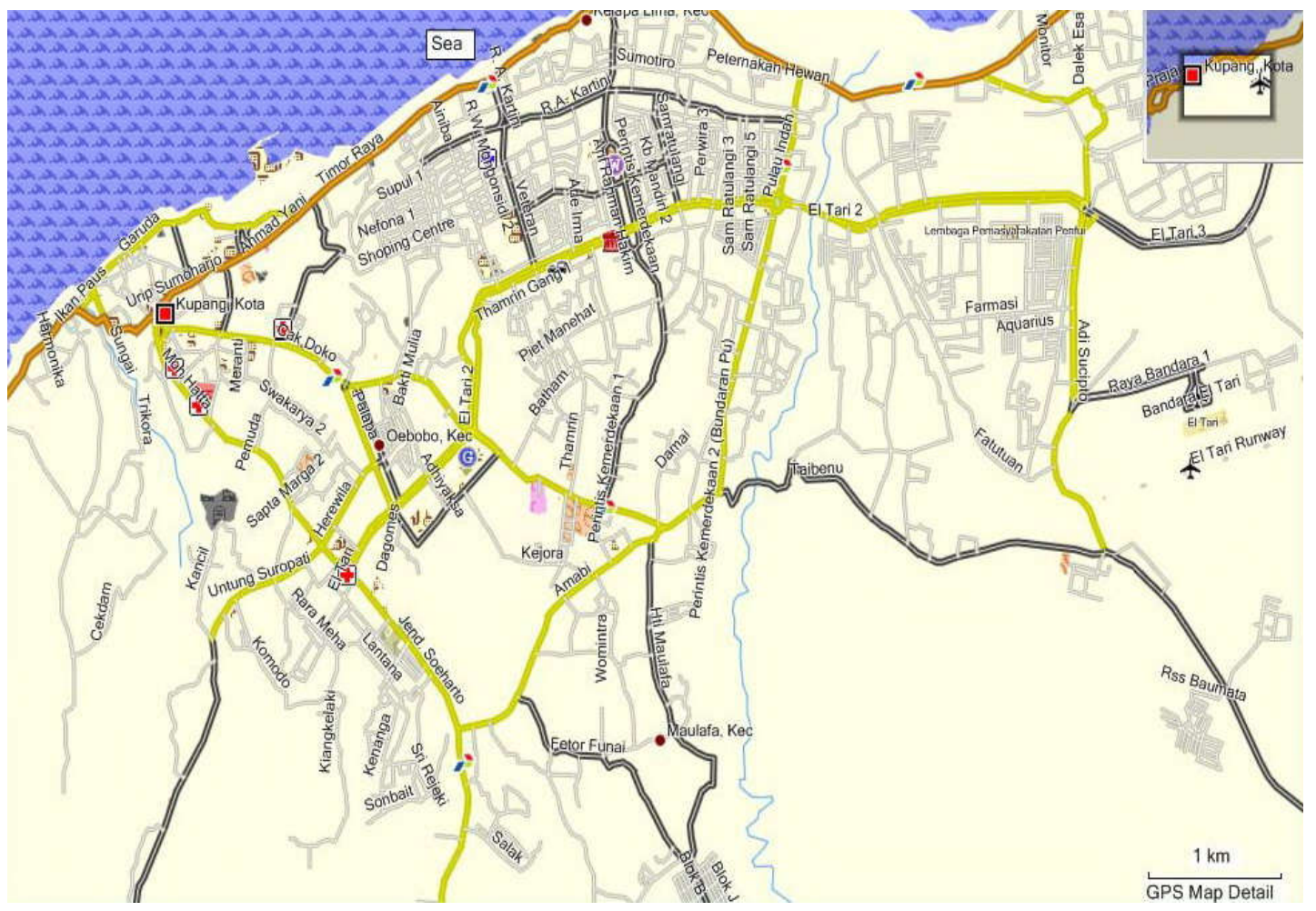

Image 1 - Map of Kupang City, East Nusa Tenggara Indonesia

Meanwhile, primary data will be collected using the Participatory Rural Appraisal (PRA) method, primarily using Semi-structural interview techniques (SSI) and Focus Group Discussion (FGD) techniques in urban and rural areas. SSI and FGD are conducted primarily to identify the issues and potentials of development in urban or rural areas (Konstantynova, \& Wilson.; 2014). The preparation of state development plan with participation approach begins with analyzing the collected data and based on the result will be analyzed problem and development potential followed by analysis scenario development, policy formulation policy (POST) and Logical Framework, (LOGFRAME).

Step - rare Analysis The problems encountered are related to each other in a very complex relationship so to analyze it is required step-by-step as follows: 1 . Identify the problem deductively through the situation analysis by reproducing identified priority issues. 2. Identify the problem through the FGD and SSI in which to work with the community. 3. Determine the relationship of the problem using the Table and the part of the causal relationship caused by the problem and the problems of FGD and SSI results with the community. 4. Determine priority issues by using matrix matrices by presenting problems as rows and matrices columns and hereafter assigning one value if in-line problems cause problems in columns and instead provide value 0 (Moodysson., Trippl., \& Zukauskaite; 2015). Furthermore the bias or column values are summed to obtain the corrective factors used to determine the score for each problem.

Potential analysis is done with similar steps, but in potential analysis identified the potential and potential potential derivatives (Field and Burch, 1988). Whereas the potential of priority is analyzed by interacting matrix techniques between each potential potential and each potential priority thereby it will obtain the potential of the policy that should be prioritized for its development and the potential derivative of a given potential priority can be used to develop the fundamental potentials in addressing the major problems have been identified before. 
The Group's Interest Analysis Steps are conducted by identifying the group of people most concerned with the issues and potential identified in relation to the interests of each group. Community groups are identified through situational analysis as well as through FGD and SSI.

Finally, some suggestions and suggestions will be presented in this study so that stakeholders at the Kupang City level of the Province of East Nusa Tenggara Indonesia and the central government are expected to design future development in Kupang City of East Nusa Tenggara Province Indonesia will be more beneficial to all members of the community.

\section{RESULTS OF STUDY}

Analysis and identification aimed at knowing the basics of the region in the regional economy needs to be done, without neglecting other sectors or non-base sectors. Baseline sectors have always had a multiplier effect or multiplier effect in the local economy, resulting in the stimulus of the economic activities of non-base sectors to grow and grow (Elhorst, de Haan, Zandberg.; 2013).

For that reason, what will happen and what is expected from the structure of the economy in the future has a very important meaning, so that it can be used as a component in the basic framework and development strategy in the future. On that basis, to support the achievement of the economic development goals of Kupang City of East Nusa Tenggara in the future, especially in preparing for long term development within the framework of regional autonomy, it is necessary to use intensive method of economic planning in analyzing and evaluating regional economic potential and economic condition areas that have been achieved in the past 15 years, ie, 2001 to 2015.

Intensive analysis and evaluation of the potentials and conditions in question will identify which sectors have been well developed and the extent to which they contribute to the increase of people and local income (Frenken, Van Oort., \& Verburg 2007). Here also can be seen, what sector is actually a priority to be developed and whether it is in accordance with the policy that has been done by the government which is reflected in the Regional Budget Income (APBD) every budget year. The performance of the regional economic structure for 15 years can provide input for the government in Kupang City of East Nusa Tenggara Indonesia in determining the direction in preparing regional development planning in the future.

From the results of secondary data, direct observation in the field and interviews with selected villagers can be identified the potential of the physical environment and natural resources in the Kupang City of East Nusa Tenggara Province Indonesia which consists of the main potential ie service area, These include: erosion and flood, limited water resources, fires, more exploitation of natural resources, and income.

Therefore, to see the circumstances of each development plan must be properly understood for the user and its implementation in the field so that they are able to perform a practical approach that is well suited to the economic condition, in which the development is carried out. Through data that has been processed in the form of a logical thinking framework as it is presented. Therefore, the development priority in Kupang City of East Nusa Tenggara Province of Indonesia can be frozen into programs and projects that may be possible as a logical framework to see the potential of the problem. This logical sense framework is expected to be able to formulate a detailed design plan of the program and the description of the development project to be implemented.

Strategy of planning and economic development policy. The Policy of Law Number 22 Year 1999 of the Republic of Indonesia concerning Regional Government and Law Number 25 Year 1999 Concerning Financial Balance between Central and Regional Government, stipulates the emphasis of regional autonomy on districts and cities. Districts and municipalities are given wide authority as autonomous regions to regulate and manage the interests of local communities based on democratic principles, initiatives and aspirations of the people themselves, on the basis of equity and justice and in accordance with the conditions, potential and diversity of its territory. In particular, this authority is regulated in 
Law Number 22 Year 1999 Article 11 stating that: (1). The Regional Authorities of the Regency and the City Area shall include all governmental authorities other than the authority exempted in article 7 and provided for in article 9., (2). Areas of government that must be implemented by districts and municipalities include public works, health, education and culture, agriculture, transportation, industry and trade, capital investment, environment, land, cooperatives and labor.

Thus, the law has given wider authority to the regions in terms of governance and development either in the planning, implementation, monitoring and evaluation phases. Including the authority to determine the policy direction and choose alternative ways of handling development in their respective regions. The economic development policy adopted by a region should be adjusted to the conditions and potentials of natural resources, human resources, facilities and infrastructure available in the region (Aba., Yussof, Saidatulakmal, 2015). This reality occurs because economic development does not always occur in the region simultaneously. Several sectors achieved rapid growth, while other sectors experienced slow growth and even decline (Arts, Vaan, 2010).

The economic growth of Kupang City of East Nusa Tenggara Indonesia shows that from 2007 to 2011 the economic growth rate was quite good in 2007 of $9.00 \%$, in 2008 slowed to $7.45 \%$ and in 2009 also experienced a slowdown to $6.13 \%$ whereas in 2010 it accelerated to $8.23 \%$ and in 2011 reached $8.26 \%$. Looking at the economic growth trend in Kupang City of East Nusa Tenggara Province Indonesia for the last five years with annual growth rate of $0.59 \%$ it can be predicted by the end of 2017 economic growth in Kupang City of East Nusa Tenggara Province Indonesia reaches approximately $11.46 \%$ (BPS, 2001 2015). This economic growth can be achieved if the assumption of security and order conditions can be maintained conducively, the increase of investment amount, the controlled amount of inflation and the increase of non-oil exports.

In this regard the role of planning is the key to a good process of economic development (Tödtling \& Trippl.; 2005). Economic development policy planning of each region should select priorities in sectors that match the capability and potential of the regional power. The principle of regional economy consists of two sectors, namely sectors that have advantages so as to contribute in a large portion of the proportion of exports of goods and services to other areas, these are referred to as basic activities activities, and activities that provide goods and services are limited to the needs of the region itself or not exporting, these are referred to as non-basic activities activities (Ruming, Davies, 2014).

The aim of the basic assessment of development planning is the process of implementation of the development of the participation and at the same time want to see the understanding of society on the terminology of participation development as well as the result of the implementation of the development in the form of participation (Approach.; 2003). Therefore, the purpose of the design is to provide basic action information, innovation, and solutions for the process of allocation of public resources and the optimization of available resources. Substantial or intense and robust strategic planning and technical or operational planning are in fact related to the macro (general) and micro (specific) systems, which are essentially a combination of socio-economic and environmental physics, and also include products arrangements resulting from political consensus, economic feasibility, and technical solutions to benefit society.

The important implications of designing are: (1) The ability of society as individual, family, and society as a perpetrator for the process of socioeconomic change, (2). The more accommodative socio-politics of the community and market development processes, (3). Development of development institution capacity, (4). Availability of basic, innovative, and technical information can be used as a decision maker for stakeholders.

Economic structure in the formation of GRDP in 2001-2015. The contribution of every economic sector in Kupang City of East Nusa Tenggara Province Indonesia in the formation of GRDP can illustrate the economic structure of Kupang City of East Nusa Tenggara Province of Indonesia. The contribution of the sector is the contribution or share given by each sector to the Kupang City GRDP in the East Nusa Tenggara Province of Indonesia. In the period 2001-2015 the economic structure in Kupang City of East Nusa Tenggara 
Province Indonesia has not changed much. The manufacturing, trading, restaurant and hotel sectors, Transportation and Communications, Banks and Financial Institutions and services sector continue to dominate the economy in Kupang City of East Nusa Tenggara Province Indonesia to date and become the leading sector as the economic base for the period.

In the period 2001-2015, economic growth in Kupang City of East Nusa Tenggara Province Indonesia is still considered stable and fluctuating, with the highest growth in 2002, and the lowest in 2005, excluding 2003 and 2010 (table1).

Table 1 - Growth of GAV and GDP of Kupang City Based on Constant Price 1993, 2000 and 2010, Years 2001-2015

\begin{tabular}{|cccccccccccc|}
\hline \multirow{2}{*}{ No. } & Year & Sector 1 & Sector 2 & Sector 3 & Sector 4 & Sector 5 & Sector 6 & Sector 7 & Sector 8 & Sector 9 \\
1 & 2001 & - & - & - & - & & - & - & - & - \\
2 & 2002 & 3.87 & 0.34 & 2.86 & 1.66 & 3.23 & 6.51 & 17.99 & 2.11 & 11.65 \\
3 & 2003 & 238.46 & 215.75 & 90.57 & 27.30 & 255.64 & 187.74 & 64.28 & 117.37 & 152.24 \\
4 & 2004 & 5.50 & 5.95 & 6.27 & 6.10 & 4.56 & 6.31 & 6.91 & 5.27 & 6.76 \\
5 & 2005 & 3.10 & 0.46 & $(1.26)$ & $(9.16)$ & 6.46 & 10.23 & 8.17 & $(0.94)$ & 1.00 \\
6 & 2006 & 4.43 & 4.56 & 5.03 & 4.56 & 3.60 & 5.18 & 5.82 & 4.11 & 5.94 \\
7 & 2007 & 4.93 & 6.79 & 4.31 & 14.95 & 6.75 & 5.09 & 8.13 & 4.89 & 5.75 \\
8 & 2008 & 6.74 & 4.68 & 5.57 & 16.61 & 3.06 & 6.71 & 8.28 & 11.73 & 6.91 \\
9 & 2009 & 2.49 & $(7.44)$ & $(1.11)$ & $(21.22)$ & 2.76 & 7.55 & 16.25 & 31.25 & 6.54 \\
10 & 2010 & 138.92 & 231.94 & 145.80 & 28.16 & 4.25 & 259.38 & 265.02 & 643.68 & 241.67 \\
11 & 2011 & 4.01 & 3.93 & 3.08 & 8.49 & 2.78 & 8.43 & 13.06 & 9.78 & 7.11 \\
12 & 2012 & 2.94 & 3.52 & 7.94 & 12.55 & 5.67 & 7.66 & 8.33 & 9.57 & 7.20 \\
13 & 2013 & 4.80 & 4.13 & 5.51 & 9.36 & 5.76 & 8.51 & 5.13 & 9.98 & 6.56 \\
14 & 2014 & 5.45 & 3.16 & 4.64 & 13.43 & 5.91 & 6.05 & 9.92 & 9.27 & 5.69 \\
15 & 2015 & 6.56 & 3.33 & 5.11 & 9.54 & 6.21 & 6.67 & 8.93 & 6.63 & 5.41 \\
\hline
\end{tabular}

Notes: Sector 1: Agriculture; Sector 2: Mining and Quarrying; Sector 3: Processing Industry; Sector 4: Electricity, Gas and Water Supply; Sector 5: Building; Sector 6: Trade, Hotel and Restaurant; Sector 7: Transportation and Communication; Sector 8: Finance, Leasing and Corporate Services; Sector 9: Services.

While the contribution of each economic sector to GRDP varies, where sector Trade, Hotel and Restaurant has the largest contribution to GRDP in Kupang City of East Nusa Tenggara Indonesia Province in the period 2001-20015 table 2.

Table 2 - Percentage Distribution Per Sector Contribution to Kupang City Regional GDP on the basis of Constant Price 1993, 2000 and 2010, 2001-2015 (\%)

\begin{tabular}{|ccccccccccc|}
\hline \multirow{2}{*}{ No. } & Year & Sector 1 & Sector 2 & Sector 3 & Sector 4 & Sector 5 & Sector 6 & Sector 7 & Sector 8 & Sector 9 \\
1 & 2001 & 4.06 & 1.78 & 5.07 & 2.42 & 6.03 & 25.41 & 19.76 & 6.13 & 29.34 \\
2 & 2002 & 3.85 & 1.64 & 4.77 & 2.25 & 5.69 & 24.76 & 21.33 & 5.73 & 29.98 \\
3 & 2003 & 5.33 & 2.11 & 3.71 & 1.17 & 8.27 & 29.11 & 14.32 & 5.09 & 30.89 \\
4 & 2004 & 5.29 & 2.11 & 3.71 & 1.17 & 8.14 & 29.12 & 14.40 & 5.04 & 31.03 \\
5 & 2005 & 5.20 & 2.02 & 3.49 & 1.01 & 8.25 & 30.58 & 14.84 & 4.75 & 29.86 \\
6 & 2006 & 5.16 & 2.00 & 3.49 & 1.00 & 8.12 & 30.55 & 14.92 & 4.70 & 30.05 \\
7 & 2007 & 5.10 & 2.02 & 3.43 & 1.09 & 8.18 & 30.30 & 15.23 & 4.65 & 29.99 \\
8 & 2008 & 5.09 & 1.98 & 3.39 & 1.19 & 7.89 & 30.23 & 15.41 & 4.86 & 29.97 \\
9 & 2009 & 4.83 & 1.69 & 3.09 & 0.87 & 7.49 & 30.05 & 16.56 & 5.90 & 29.52 \\
10 & 2010 & 3.32 & 1.62 & 2.19 & 0.32 & 2.25 & 31.14 & 17.43 & 12.65 & 29.08 \\
11 & 2011 & 3.19 & 1.55 & 2.08 & 0.32 & 2.13 & 31.10 & 18.15 & 12.79 & 28.69 \\
12 & 2012 & 3.05 & 1.49 & 2.09 & 0.33 & 2.09 & 31.10 & 18.26 & 13.01 & 28.57 \\
13 & 2013 & 2.98 & 1.45 & 2.05 & 0.34 & 2.06 & 31.47 & 17.91 & 13.35 & 28.39 \\
14 & 2014 & 2.93 & 1.39 & 2.01 & 0.36 & 2.04 & 31.19 & 18.39 & 13.63 & 28.04 \\
15 & 2015 & 2.93 & 1.35 & 1.98 & 0.37 & 2.03 & 31.20 & 18.79 & 13.63 & 27.72 \\
\multicolumn{2}{l}{ Total } & 62.31 & 26.2 & 46.55 & 14.21 & 80.66 & 447.31 & 255.7 & 125.91 & 441.12 \\
\hline
\end{tabular}

Information: Sector 1: Agriculture; Sector 2: Mining and Quarrying; Sector 3: Processing Industry; Sector 4: Electricity, Gas and Water Supply; Sector 5: Building; Sector 6: Trade, Hotel and Restaurant; Sector 7: Transportation and Communication; Sector 8: Finance, Leasing and Corporate Services; Sector 9: Services.

The economy in Kupang City of East Nusa Tenggara Indonesia Province in 2015 has decelerated compared to the growth of previous years. The growth rate of Kupang city 
GRDP by 2015 reaches 6.65 percent, while in 2014 it is 7.00 percent. The highest economic growth was achieved by the field of Electricity, Gas and Water Supply 9.54 percent. In the data above shows the entire economic field of GDP in 2015 experienced a positive growth. The other three business fields that experienced high growth were 8.93 percent of the transportation and communication business, the trade, hotel and restaurant fields recorded 6.67 percent and the fi eld of fi nance, leasing and business services 6.63 percent.

GRDP per capita in Kupang City of East Nusa Tenggara Province Indonesia has increased every year as the population increase over the period of 2001-2015, where the year 2015 is Indonesia Rupiah / IDR. 7,234,165 (table 3).

Table 3 - Population, GRDP and GRDP Per Capita Kupang City, East Nusa Tenggara Indonesia, Years 2001-2015

\begin{tabular}{|cccc|}
\hline Year & Population & PGRDP & GRDP Per Capita \\
2001 & 245300 & $530,987,287$ & 1992407 \\
2002 & 252550 & $580,374,680$ & 2009782 \\
2003 & 259900 & $1,420,566,692$ & 4801430 \\
2004 & 262699 & $1,509,818,272$ & 5016993 \\
2005 & 271882 & $1,584,715,912$ & 5114180 \\
2006 & 279124 & $1,668,042,356$ & 5239736 \\
2007 & 286299 & $1,767,529,907$ & 5613091 \\
2008 & 292922 & $1,890,777,450$ & 5787903 \\
2009 & 299518 & $2,045,332,810$ & 6104116 \\
2010 & 336239 & $7,094,195,026$ & 6172893 \\
2011 & 348673 & $7,701,370,220$ & 6240176 \\
2012 & 358382 & $8,291,239,644$ & 6305329 \\
2013 & 368199 & $8,890,995,786$ & 6578325 \\
2014 & 384112 & $9,513,553,099$ & 6723542 \\
2015 & 390877 & $10,145,836,797$ & 7234165 \\
\hline
\end{tabular}

Viewed from the components of population change that birth rates indicate a tendency to decline, while relative mortality rates are declining. Life expectancy also shows an increase, which means that there is an increase in the health of the population or increase the awareness of the people's knowledge of healthy living. Workforce issues are one of the difficult issues to be solved by the current economic and financial crisis. The data available in the labor department in the Kupang City of East Nusa Tenggara Indonesia by the BPS of Kupang City of East Nusa Tenggara Province, Indonesia showed that the number of job seekers is much greater than the availability of existing jobs. Every year job seekers and new workforce tend to increase, while new job growth is not as fast as the growth of the labor force, as a result of increasing unemployment each year. This statement illustrates that the primary business field must remain the mainstream of the regional economy by continuously expanding the economic base sector in the industry and services sectors.

Finally, basically the key values in planning policy evaluation activities are market rationality and socio-political rationality, which influence the planning process and action. It has the goals of values such as openness, responsibility, justice, and participation or democracy. Its open-ended planning is an easy-to-understand planning process, where information on technical information and technical inputs and information is available and access is open, and stakeholders can know what role is played in decision-making or engaging in planning action.

Responsible planning has the characteristics of others being accountable and accepted by the community, in accordance with established goals, efficient use of resources, effective in solving problems, providing flexibility and convenience, and seeing the public's interest. Fair planning has its characteristics, among others, to see the balance between individual rights and to provide the poor people with access and the ability to obtain the necessary resources. Participating planning can be characterized as a plan that adopts interactive, equality, and cooperative principles in the decision making process together by considering the aspirations of all stakeholders who are interested in the well-being of the public. 


\section{DISCUSSION OF RESULTS}

Based on the results of the study, the baseline assessment of development planning in Indonesia is generally and especially in the Kupang City of East Nusa Tenggara Province, witnessing the central government to play a dominant role in the development and planning of the country as a whole. This is because the federal government has the capability of funds coming from oil and foreign and domestic aid loans. Meanwhile, government at the state level as well as the community or the private sector does not have the capability. That is why the federal government plays a role in almost every kind of development activities including planning. The community and the private sector only follow government plans, either as suppliers, contractors or subcontractors from government projects (Morgan, 2007). As such, the federal government stands in the forefront, while the community or the private sector supports from behind. Development planning is also conducted thoroughly and centrally and has a special organization, namely the National Development Planning Board.

Planning activities should be of interest to the community and workers at various levels of government, and there is a link between macro and micro-planning activities (Dunn.; 2004). This is the link between the round of public management and the round of project management undertaken by the public sector and the private sector. In particular, the process of regional and city design process should be transparent, responsive, and participatory as an embodiment of good governance principles that can support the achievement of community welfare goals, regional economic growth, and environmental sustainability.

Improved institutional capacity building is a must through: (i) New values that are transformed in the context of planning action. (ii) Development of planning methods and processes to respond to the dynamics of society as well as socio-economic and spatialgeographical changes. (iii). Develop vertical and horizontal working relationships between stakeholders in a harmonious manner in the design process at central and regional level. (iv). Improved human resource capability to effectively manage the functions and functions of design agencies or organizations both at the central and regional levels.

The evaluation of the district development planning with the approach to designing participation in the Kupang City of Nusa Tenggara Province Indonesia is essentially in the process of implementation, in particular the design process of the proposed strategy and development program which will certainly be adapted to the local physical, economic, social and cultural conditions. The strategies and programs presented in this study are expected to be further and more detailed studies involving all official institutions from central level, state to region and even to the village level. The design should not be done until the project level, but must reach the strategy and program. The consideration being used is that in order to arrange a project it is necessary to analyze the problem, potential, and importance of the group in more detail.

\section{CONCLUSION}

The ability to improve the design basis should also be followed by a thorough understanding of aspirations and actual needs the community as individuals, families and communities as perpetrators in the ongoing process of social transformation; the development of community participation methods in the public decision-making process of the planning and implementation of democratic plans, openness and accountability (Choguill.; 2003). To improve the planning institution, concrete steps need to be taken by coordinating and consistent with other planning processes, clarifying the division of tasks and the relationship between macro and micro-planning activities at various levels of government, changing the way the planning agencies work at various levels of government, and increasing the capacity and capabilities of resources human designer.

In order to be able to implement the policy planning upgrade, a number of strategic steps need to be taken by the planning agency, namely: (i). Increasing the capacity of designers involved in various planning activities, the designing agency should be able to take 
initiatives for insights, knowledge, and skills using new methods in the design process, (ii). Improved working relationships between institutional and planning organizations, the institute needs to interact stakeholders will be able to develop better planning processes for the benefit of the community, (iii). Enhancing services to the public requires enhanced information and communication activities that involve the development of science and technical knowledge in designing activities, and providing feedback information to design agencies or organizations, including design education institutions.

Community participation in the development process, especially in urban areas, is no longer a paradigm, but it is already a city planning science development plan phylosophy. The cities in Indonesia in general and especially in the Kupang City of East Nusa Tenggara Indonesia have been developed and developed with the old paradigm, with a top-down planning and sectoral approach. The results of the development are more than the needs of a group of people with a small percentage (exclusive society), while the needs of a larger society (marginal society) are neglected and affected.

\section{REFERENCES}

1. Aba, F.X.L., Yussof, O.M., Saidatulakmal, B.M 2015, 'Analysis of Economic Structure in Poverty Eradication in the Province Of East Nusa Tenggara Indonesia', ELSEVIER, Journal Procedia - Social and Behavioral Sciences Volume 211, 25 November 2015, Pages 81-88.

2. Allison, Graham T. (1968). Conceptual models and the Cuban missile crisis: rational policy, organizational process, and bureaucratic politics. Cambridge, Mass.: Harvard University Press.

3. Alonso, W. (1968) Industrial Location and Regional Policy in Economic Development, Working Paper No: 74, Mimeo, IURD, University of California Berkeley. In Friedman, J., and Alonso, W., (1975).

4. Arts, J. \& De Vaan, M. (2010). "Infrastructure meets area development; Developments in Dutch planning practice: towards a more balanced finance of development projects? Work in progress, Fourth conference on planning law and property rights, Dortmund.

5. Approach Yin, R. K. (2003). Case study research. Design and Methods. 3rd. (Vol. 5). In Applied social research methods series. Thousand Oaks: Sage Publications. $181 \mathrm{p}$. Retrieved from https://books.google.es/books?id=BWea_9ZGQMwC\&printsec=frontcover\&source=gbs_ ge_summary_r\&cad $=0 \# v=$ onepage $\& q \& f=$ false

6. Badan Pusat Statistik (BPS), (2001- 2016). Kota Kupang dan NTT Dalam Angka / East Nusa Tenggara in Figures.

7. Boschma, R., \& Martin, R. (2010). The handbook of evolutionary economic geography. Cheltenham: Edward Elgar. Coenen, L., Moodysson, J., \& Martin, H. (2014). Path renewal in old industrial regions: Possibilities and limitations for regional innovation policy. Regional Studies, 49, 850-865.

8. Choguill, C. 2003. Community infrastructure for low-income cities: The potential for progressive improvement. Habitat International, 23(2), 289-301.

9. Dinc M, Haynes KE (1998) International trade and shift-share analysis: A specification note. Economic Development Quarterly 12(4):337-343.

10. Dolgoff, R. \& Feldstein, D. (2009). Social work: The emergence of profession. In Understanding social welfare: A search for social justice (7th ed.) (pp. 299-318). Boston, MA: Pearson Education.

11. Dunn, WN. 2004. Public Policy Analysis: An Introduction. Ed ke-2. Prentice-Hall, Inc., A Simon \& Schuster Company, Englewood Cliffs, New Jersey 07632.

12. Eichengreen, B., P. Donghyung, and S. Kwanho.(2012). "When Fast Growing Economies Slow Down: International Evidence and Implications for China." Asian Economic Papers 11(1): 42-87. 
13. Elhorst, J.P., de Haan, J., Zandberg, E., (2013). The impact of interaction effects among neighboring countries in financial liberalization and reform: a dynamic spatial panel data approach.

14. Elson, Anthony. (2013). Globalization and Development: Why East Asia Surged Ahead and Latin America Fell Behind. New York: Palgrave MacMillan.

15. Field, R. D. and Burch, W. R. 1988. Rural Sociology and the Environment Social Ecology Press, Middletown, Wisconsin.

16. Frenken, K., Van Oort, F., \& Verburg, T. (2007). Related variety, unrelated variety and regional economic growth. Regional Studies, 41, 685-697.

17. Healey, P. (1996) 'The Communicative Turn in Planning Theory and its Implication for Spatial Strategy-making', Environment \& Planning 23: 217-34.

18. Healey, P. (1997) Collaborative Planning. London: Macmillan Press.

19. Konstantynova, A., \& Wilson, R. J. (2014). Comparing cluster policies: an analytical framework. Orkestra Working Paper Series in Territorial Competitiveness 2014-R01. Deusto Maskell, P., \& Malmberg, A. (1999). Localised learning and industrial competitiveness. Cambridge Journal of Economics, 23, 167-185.

20. Moodysson, J., Trippl, M., \& Zukauskaite, E. (2015). Papers in innovation studies policy learning and smart specialization balancing policy change and policy stability for new regional industrial path development. CIRCLE Publications.

21. Morgan, K. J. (2007). The learning region: Institutions, innovation and regional renewal. Regional Studies, 31, 491-503. doi:10.1080/00343409750132289

22. Ruming, K.J., Davies, P.J., (2014). To what extent 'an entirely new approach to how planning is done?' Tracing planning system reform in New South Wales. Aust. Plann. 52 (2), 122-131.

23. Tödtling, F., \& Trippl, M. (2005). One size fits all? Towards a differentiated policy approach with respect to regional innovation systems. Research Policy, 34, 1203-1219. Retrieved from https://www.researchgate.net/

24. Van der Mensbrugghe, D (2013). "Modeling the Global Economy: Forward Looking Scenarios for Agriculture." In Handbook of Computable General Equilibrium Modeling, ed. P.B. Dixon and D.W. Jorgenson, 933-94. North Holland: Elsevier B.V. 